\title{
Effect of Local Administration of Lymphokine-activated Killer Cells and Interleukin-2 on Malignant Brain Tumor Patients
}

\author{
Yukihiro IBAYASHI, Toshiaki YAMAKI, Takahisa KAWAHARA, \\ Masahiko DAIBo, Tsukasa Kubota, Teiji UEDE, Sumiyoshi TANABE \\ and Kazuo HASHI
}

Department of Neurosurgery, Sapporo Medical College, Sapporo

\begin{abstract}
Nine patients with malignant brain tumors were treated with intratumoral infusion of lymphokine-activated killer (LAK) cells and interleukin-2 (IL-2). LAK cells were generated from macrophagedepleted peripheral blood lymphocytes by culturing with IL-2 for 4 days. The resulting LAK cells showed strong cytotoxic activity against tumor target cells. Three patients received sufficient LAK cells $\left(\geqq 5.76 \times 10^{8}\right.$ ) to show partial tumor response by computed tomography and clinical signs. No severe neurological side effects occurred in any patient. Intratumoral administration of LAK cells and IL-2 can be effective in patients with malignant brain tumors.
\end{abstract}

Key words: lymphokine-activated killer cell, interleukin-2, malignant tumor, immunotherapy, glioma

\section{Introduction}

Patients with malignant brain tumors are a major therapeutic challenge. Current therapy for glioblastoma multiforme patients consists of surgery, radiation, and chemotherapy providing a median survival of approximately 50 weeks. ${ }^{26,27)}$ The combination of radiation and chemotherapy has improved the prognosis for brain tumor patients, but also has serious side effects. Immunotherapy can potentially destroy the malignant tumor specifically without damaging normal brain tissue. Various immunotherapy methods have been developed, ${ }^{22,30)}$ but clinical approaches with biological response modifiers such as interferon, monoclonal antibody $(\mathrm{MoAb})$, and levamisole have achieved limited therapeutic efficacy. ${ }^{14,23)}$

Culture of human peripheral blood lymphocytes (PBLs) with interleukin-2 (IL-2) in the absence of other stimuli generates cells that are cytotoxic against many malignant target cells. ${ }^{4)}$ These lymphokine-activated killer (LAK) cells will also lyse allogeneic

Received September 11, 1992; Accepted November 9,1992 glioblastoma targets but not normal cells in in vitro ${ }^{51} \mathrm{Cr}$ release assays. ${ }^{11)}$ We previously induced LAK cells from macrophage-depleted PBLs of patients with malignant brain tumors by incubation with IL$2 .{ }^{\text {") }}$ The resultant LAK cells had strong cytotoxic activity against target cells including natural killer (NK)-sensitive, NK-resistant, and autologous tumor cells. Here, we report the results of clinical studies designed to investigate the effectiveness of intratumoral administration of LAK cells and IL-2.

\section{Materials and Methods}

\section{Patient selection}

Table 1 shows the nine patients, four females and five males, included in this study. Histological diagnoses of the tumors were: four anaplastic astrocytomas, three glioblastomas, one malignant histiocytoma, and one metastatic cerebellar tumor. Patients receiving radiation or chemotherapy in the preceding 4 weeks were excluded from the study. All patients had progressive disease documented by clinical examination and computed tomography (CT). Informed consent was obtained from all patients before initiation of immunotherapy. 
Table 1 Patient profile treated with LAK cells and IL-2

\begin{tabular}{|c|c|c|c|c|c|c|c|c|}
\hline \multirow{2}{*}{$\begin{array}{l}\text { Case } \\
\text { No. }\end{array}$} & \multirow{2}{*}{$\begin{array}{l}\text { Age' } \\
\text { Sex }\end{array}$} & \multirow{2}{*}{ Diagnosis } & \multicolumn{2}{|c|}{ Total dosage } & \multirow{2}{*}{$\begin{array}{l}\text { Clinical } \\
\text { results }\end{array}$} & \multirow{2}{*}{$\begin{array}{l}\text { Tumor } \\
\text { response } \\
\text { by } \mathrm{CT}^{*}\end{array}$} & \multirow{2}{*}{$\begin{array}{l}\text { Complica- } \\
\text { tion }\end{array}$} & \multirow{2}{*}{$\begin{array}{l}\text { Survival } \\
\text { after } \\
\text { treatment }\end{array}$} \\
\hline & & & LAK cells $\left(\times 10^{7}\right)$ & $\mathrm{IL}-2(\times 100 \mathrm{U})$ & & & & \\
\hline 1 & $49 / \mathrm{M}$ & $\begin{array}{l}\text { anaplastic } \\
\text { astrocytoma }\end{array}$ & 93.7 & 49 & improved & PR & $\begin{array}{l}\text { wound } \\
\text { infection }\end{array}$ & $\begin{array}{l}\text { died } \\
\text { (11 mos) }\end{array}$ \\
\hline 2 & $37 / \mathrm{M}$ & $\begin{array}{l}\text { anaplastic } \\
\text { astrocytoma }\end{array}$ & 15.1 & 24 & unchanged & $\mathrm{NC}$ & $\begin{array}{l}\text { wound } \\
\text { infection }\end{array}$ & $\begin{array}{l}\text { alive } \\
\text { (54 mos) }\end{array}$ \\
\hline 3 & $46 / \mathrm{M}$ & $\begin{array}{l}\text { anaplastic } \\
\text { astrocytoma }\end{array}$ & 17.4 & 4 & unchanged & $\mathrm{NC}$ & none & $\begin{array}{l}\text { died } \\
\quad(7 \text { mos })\end{array}$ \\
\hline 4 & $56 / \mathrm{F}$ & $\begin{array}{l}\text { malignant } \\
\text { histiocytoma }\end{array}$ & 5.5 & 3 & unchanged & PD & none & $\begin{array}{l}\text { died } \\
\quad(3 \mathrm{mos})\end{array}$ \\
\hline 5 & $56 / \mathrm{F}$ & $\begin{array}{l}\text { metastatic } \\
\text { cerebellar } \\
\text { tumor }\end{array}$ & 5.9 & 2 & unchanged & PD & none & $\begin{array}{l}\text { died } \\
\quad(1 \mathrm{mo})\end{array}$ \\
\hline 6 & $37 / \mathrm{M}$ & $\begin{array}{l}\text { glioblastoma } \\
\text { multiforme }\end{array}$ & 74.0 & 24 & improved & CR & none & $\begin{array}{l}\text { alive } \\
\quad(60 \mathrm{mos})\end{array}$ \\
\hline 7 & $41 / \mathrm{M}$ & $\begin{array}{l}\text { anaplastic } \\
\text { astrocytoma }\end{array}$ & 51.8 & 18 & unchanged & $\mathrm{NC}$ & $\begin{array}{r}\text { decreased } \\
\text { general } \\
\text { activity }\end{array}$ & $\begin{array}{l}\text { died } \\
\quad(18 \mathrm{mos})\end{array}$ \\
\hline 8 & $56 / F$ & $\begin{array}{l}\text { glioblastoma } \\
\text { multiforme }\end{array}$ & 57.6 & 16 & improved & PR & none & $\begin{array}{l}\text { died } \\
\quad(10 \mathrm{mos})\end{array}$ \\
\hline 9 & $64 / \mathrm{F}$ & $\begin{array}{l}\text { glioblastoma } \\
\text { multiforme }\end{array}$ & 25.2 & 7 & unchanged & $\mathrm{NC}$ & none & $\begin{array}{l}\text { died } \\
\quad(16 \mathrm{mos})\end{array}$ \\
\hline
\end{tabular}

${ }^{*} \mathrm{CR}$ : complete response, PR: partial response, $\mathrm{NC}$ : no change, PD: progressive disease.

\section{Trial design}

Seven patients (Cases 1-3 and 6-9) received craniotomy for tumor removal followed by placement of a catheter leading from an Ommaya reservoir placed under the galea into the tumor cavity. In five of these patients (Cases 3 and 6-9) LAK cells and IL-2 (100 U) were injected directly into the tumor cavity through the Ommaya reservoir system twice a week and continued for 2-12 weeks. Two other patients (Cases 1 and 2 ) received daily intratumoral administration of IL-2 (100 U) (Fig. 1).

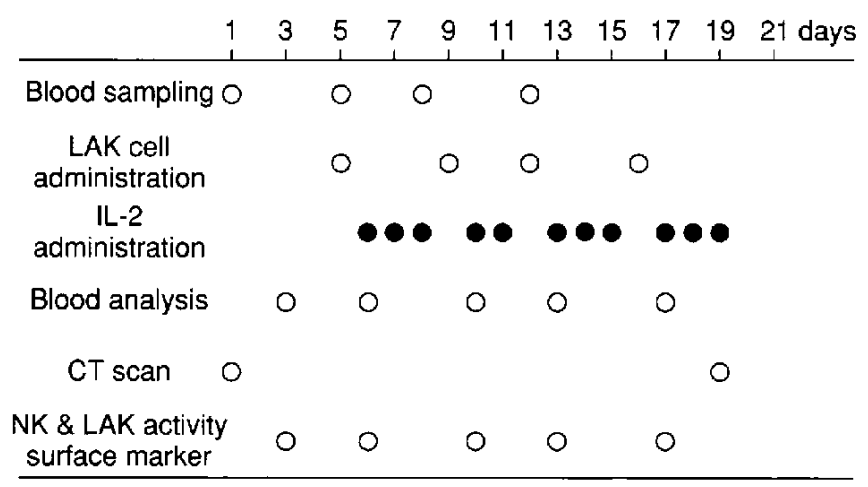

Fig. 1 Relative timing of individual immunotherapy and examinations in the first two patients (Cases 1 and 2) who received daily injection of IL-2 $(\bullet)$.
Two remaining patients (Cases 4 and 5) were given LAK cells and IL-2 intrathecally two or three times. Table 1 shows total dosages of LAK cells and IL2. A complete history and physical examination, chest radiograms, postcontrast CT scans, and electrocardiograms were obtained for all patients. Complete blood laboratory studies including different white blood cell count, biochemical profile including electrolytes, serum creatinine, calcium, magnesium, and uric acid, serum transaminase, and alkaline phosphatase were performed. Measurements of NK and LAK activity, and lymphocyte surface marker analysis were also performed (Fig. 1).

Following immunotherapy, all patients underwent CT scans and clinical examinations. Tumor size was determined by postcontrast CT scans: complete response defined as complete absence of all radiographic signs of tumor; partial response as a $50 \%$ or greater decrease in tumor size; no change as a decrease less than $50 \%$ but increase less than $25 \%$; and progressive disease as a $25 \%$ or greater increase in tumor size.

\section{IL-2 and generation of LAK cells}

LAK cells were generated from $50 \mathrm{ml}$ of PBL from each brain tumor patient before immunotherapy. PBLs were centrifuged on Ficoll-Paque (Pharmacia, Piscataway, N.J., U.S.A.) density gradients and 
adherent cells were depleted by adherence to plastic tissue culture dishes (Falcon 1029; Falcon Labware, Oxnard, Cal., U.S.A.) for 1 hour. ${ }^{6)}$ The macrophage-depleted lymphocytes were washed three times and resuspended in complete medium consisting of RPMI 1640 medium (GIBCO, Grand Island, N.Y., U.S.A.), containing L-glutamine (2 $\mathrm{mM} / \mathrm{dl})$, sodium pyruvate $(0.01 \mathrm{mM} / \mathrm{dl})$, non-essential amino acids $(1 \mathrm{ml} / \mathrm{dl})$, streptomycin $(100 \mu \mathrm{g} /$ $\mathrm{ml})$, and penicillin $(100 \mathrm{U} / \mathrm{ml})$, supplemented with $10 \%$ human AB serum (Flow Laboratory, McLean, Va., U.S.A.). LAK cells were induced by in vitro incubation for 4 days with $10 \mathrm{U} / \mathrm{ml}$ of purified human recombinant IL-2 (Takeda Chemical Industries, Ltd., Osaka), which had a specific activity of $3.5 \times 10^{4} \mathrm{U} / \mathrm{mg}$ protein by IL-2-dependent murine NKC 3 cell assay. ${ }^{5)}$ This concentration of IL-2 was shown previously to induce strong cytotoxic activity. ${ }^{6)}$ Macrophage-depleted PBLs were cultured in $75 \mathrm{~cm}^{2}$ flasks (Costar, Cambridge, Mass., U.S.A.) in $50 \mathrm{ml}$ of complete medium at $1-2 \times 10^{6}$ cells $/ \mathrm{ml}$ in $5 \% \mathrm{CO}_{2}$ at $37^{\circ} \mathrm{C}$. After 4 days, LAK cells were harvested, washed three times with Hanks' balanced salt solution, and suspended in 1-2 ml of saline with $100 \mathrm{U}$ of IL-2. Culture and Gram staining from LAK cell suspension were performed before intratumoral administration.

\section{Target cells and cytotoxicity assay}

The NK-sensitive erythroleukemia cell line (K562) and the NK-resistant Burkitt lymphoma cell line (Daudi) were maintained in RPMI 1640 medium supplemented with $10 \%$ fetal calf serum (Flow Laboratory). The Daudi cells were used as LAK targets and K562 as NK and LAK effector targets. Some experiments used enzyme-treated autologous tumor cells produced by preparation of single cell suspensions from fresh tumor specimens as described by us earlier. ${ }^{9)}$

Standard cytotoxicity assays were performed in complete medium.") Target cells were labeled with $100 \mu \mathrm{Ci}$ of sodium ${ }^{51} \mathrm{Cr}$ chromate (Amersham International, Arlington Heights, Ill., U.S.A.) for 60 minutes at $37^{\circ} \mathrm{C}$ and washed three times before use. Cytotoxicity was tested in V-shaped microwells with $200 \mu 1$ of assay medium containing $5 \times 10^{3}$ target cells and various numbers of effector cells. The assays were initiated by low-speed centrifugation ( $500 \mathrm{~g}$ for $4 \mathrm{~min}$ ) followed by incubation at $37^{\circ} \mathrm{C}$ for 4 hours. After incubation, $100 \mu 1$ of supernatant was collected from each well for counting the chromium released. Cytotoxic activity was expressed by:

$$
\begin{aligned}
& \% \text { specific lysis }= \\
& \frac{\text { experimental release }- \text { spontaneous release }}{\text { total release }- \text { spontaneous release }} \times 100
\end{aligned}
$$

Spontaneous release was determined from wells containing no effector cells and total release was obtained from wells containing target cells lysed with $5 \%$ NP 40 detergent.

\section{Immunohistological analysis}

Systemic administration of $\mathbf{I L}-2$ causes a rapid decrease in peripheral mononuclear cells with a shift to cells of macrophage lineage, and rapid decreases in total $\mathrm{T}$ lymphocytes and $\mathrm{T}$ lymphocyte subsets. ${ }^{13)}$ LAK precursor cells are a part of the Leu $7^{-}$and CD $16^{+}$large granular lymphocytes that include NK cells. ${ }^{10)}$ Therefore, we analyzed the effect of local administration of LAK cells and IL-2 on the phenotypes and cytotoxic functions of peripheral mononuclear cells. PBLs were adjusted to $0.5 \times$ $10^{6} / \mathrm{ml}$ in phosphate-buffered saline (PBS) and stained with fluorescein-labeled MoAbs specific for different surface markers of human mononuclear cells, ${ }^{8)}$ including: Leu 2a (CD 8), Leu 3a (CD 4), Leu 4 (CD 3), Leu 11b (CD 16), anti-IL-2R (CD 25), anti-human leukocyte antigen (HLA-DR) (all from Becton-Dickinson, Mountain View, Cal., U.S.A.), and OKT9 (Ortho Diagnostics, Inc., Raritan, N.J., U.S.A.). The cells were incubated with MoAbs pretitered to give optimal staining for 15 minutes at $4^{\circ} \mathrm{C}$. The stained cells were washed twice with PBS and resuspended in $200 \mu \mathrm{l} / \mathrm{ml}$ of $1 \%(\mathrm{w} / \mathrm{v})$ paraformaldehyde in the same buffer for flow cytometry analysis in a FACS analyzer (Becton-Dickinson).

An indirect immunoperoxidase analysis was also performed. Endogenous peroxidase was blocked by incubation in $3 \%$ aqueous $\mathrm{H}_{2} \mathrm{O}_{2}$ for 20 minutes. The imprints were then rinsed twice in PBS containing Triton X-100 for 5 minutes each. The appropriate MoAbs pretitered to give optimal staining were applied for 30 minutes at room temperature. After three rinses in PBS, rabbit anti-mouse immunoglobulin, diluted optimal concentration, was applied for 30 minutes. After washing with cold PBS for 30 minutes, the sections were stained by a biotin-avidin horseradish peroxidase method, with biotinized goat anti-rabbit antibody and avidin-peroxidase conjugate. ${ }^{9)}$ Reaction products were visualized with $0.05 \% 3,3$ ' $-5,5$ ' diaminobenzidine tetrahydrochloride and $0.01 \% \mathrm{H}_{2} \mathrm{O}_{2}$ in $0.05 \mathrm{M}$ Tris- $\mathrm{HCl}$ buffer $(\mathrm{pH}$ 7.6). The imprints were lightly counterstained with hematoxylin then dehydrated, washed, and mounted in Bioleit (Kouken, Tokyo). 


\section{Results}

\section{Cytotoxic activity of LAK cells}

Figure 2 shows the mean cytotoxic activity of LAK cells against NK-sensitive and NK-resistant targets. Strong LAK activity was induced in cells from all patients. Furthermore, killing activity (effector/target ratio $=20: 1$ ) of more than $40 \%$ was induced against autologous tumor cells. These results indicated that LAK activity generated from PBLs obtained from malignant brain tumor patients had adequate cytotoxic activity for immunotherapy in those patients.

\section{Changes in NK and LAK activity during im- munotherapy}

Figure 3 shows the typical changes in Case 6 . The NK activity was almost parallel to the number of Leu 11b-positive lymphocytes, while strong LAK activity was not associated with changes in NK activity. Other lymphocyte surface markers were not affected by intratumoral administration of LAK cells and IL-2 (Fig. 4). Similar results were observed in other patients.

\section{Treatment response}

Three of the nine patients who received adequate immunotherapy (Cases 1, 6, and 8) demonstrated partial or complete response (Table 1). Case 1 entered the study with a recurrent anaplastic astrocytoma in the left temporoparietal region after receiving surgery, radiation, and chemotherapy. He had a complete right hemiparesis, total motor aphasia, and

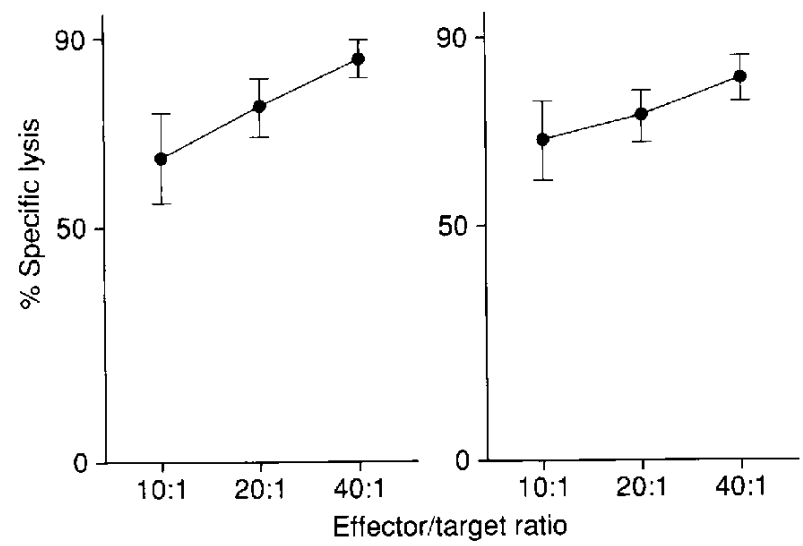

Fig. 2 Cytotoxic activity of LAK cells from all patients against K562 (left) and Daudi targets (right). Macrophage-depleted PBLs were cultured with $10 \mathrm{U} / \mathrm{ml}$ of IL-2 for 4 days and tested for LAK activity against both targets. Vertical bars indicate SD of the mean.

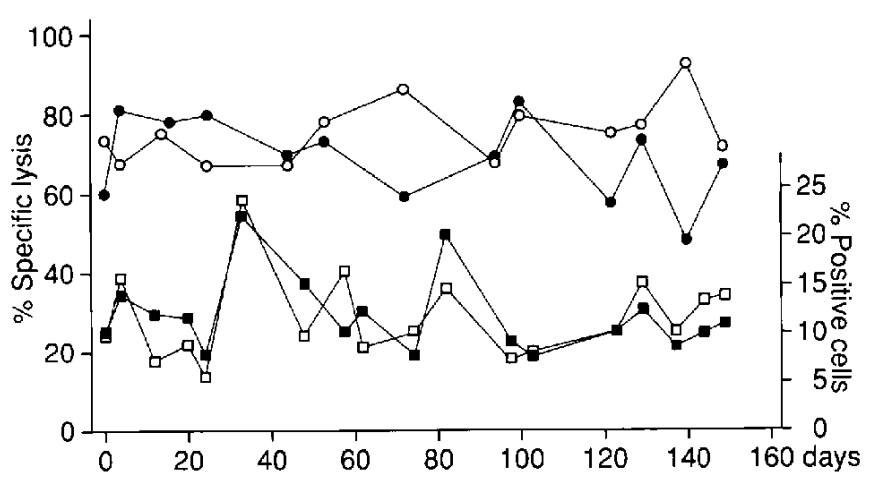

Fig. 3 Typical changes in Leu 11b-positive lymphocyte ( $\square$ ), NK activity ( $\square$ ), and LAK activity against $K 562(O)$ and Daudi targets $(\bullet)$ in Case 6. PBLs were reacted with Leu $11 \mathrm{~b}$ $\mathrm{MoAb}$ and prepared for NK cytotoxicity assays. PBLs were also cultured with $10 \mathrm{U} / \mathrm{ml}$ of IL-2 for 4 days then harvested for LAK cytotoxicity assays.

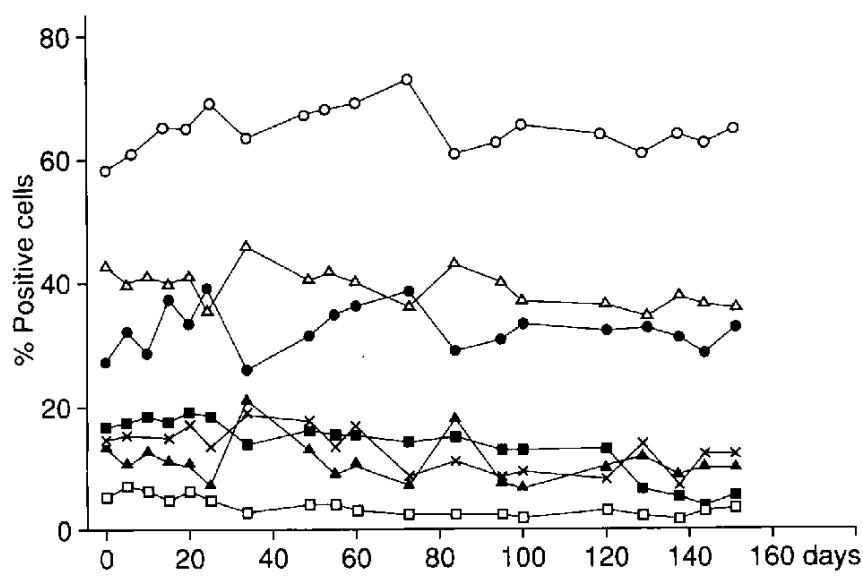

Fig. 4 Typical changes in lymphocyte surface markers in Case 6. PBLs were reacted with various types of MoAbs: Leu 2a $(\bullet)$, Leu 3a $(\triangle)$, Leu $4(0)$, Leu 11b (A), anti-1L-2R ( $)$, anti-HLA-DR $(x)$, and OKT9 $(\square)$.

decreased general activity. Three weeks after immunotherapy, postcontrast CT scans showed a decreased area of enhancement. The symptoms were slightly improved, he could speak a few words and eat by himself. However, he could not receive additional immunotherapy because of a wound infection and died 11 months after treatment.

Figure 5 shows postcontrast CT scans before and after immunotherapy in Case 8 . Three weeks after treatment with $5.9 \times 10^{7}$ of LAK cells, postcontrast CT scans showed a decreased area of enhance- 


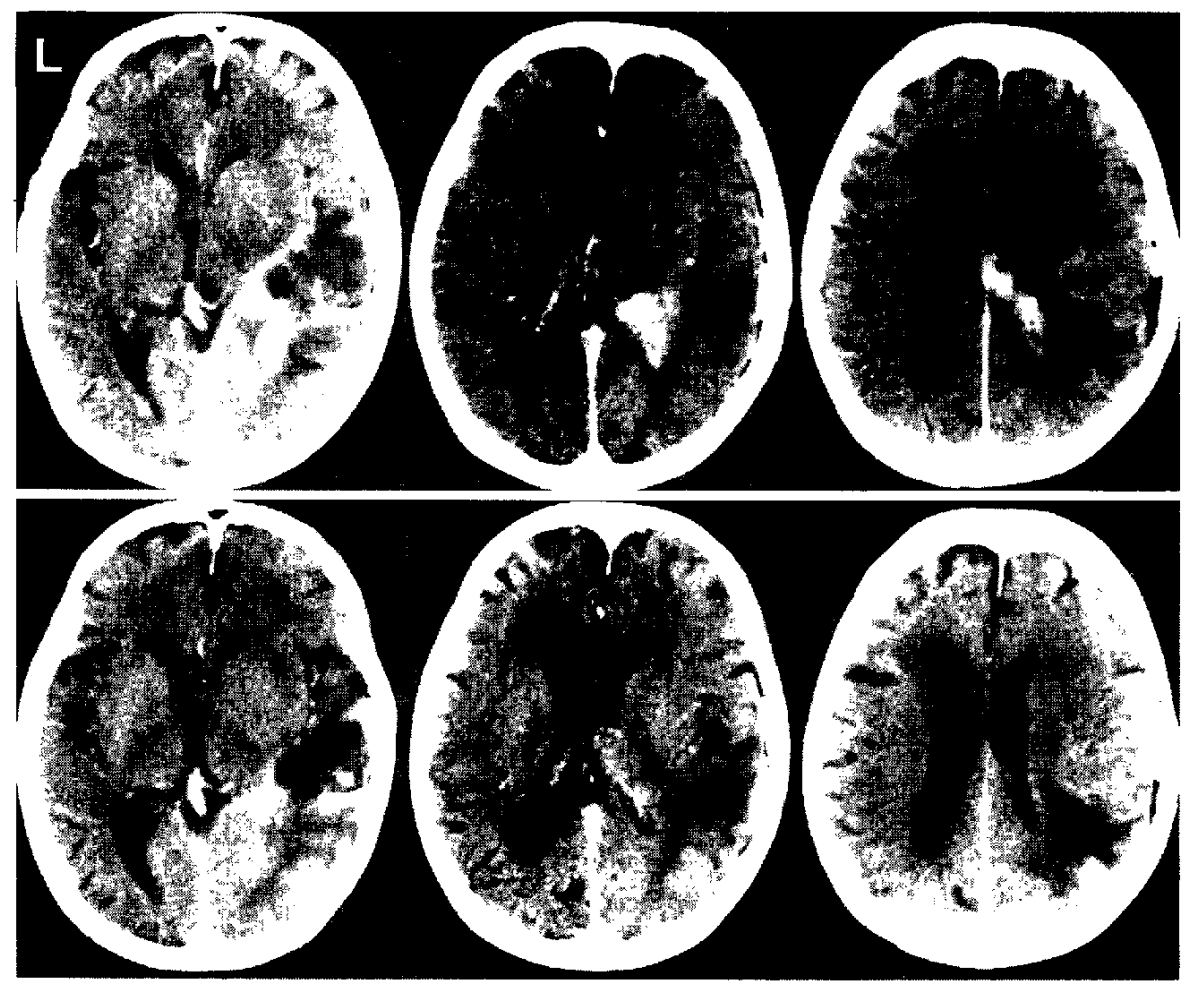

Fig. 5 Case 8. Postcontrast CT scans before (upper) and 3 weeks after immunotherapy (lower), showing decrease in tumor size.

ment in the right trigone and surrounding lowdensity area. The tumor size remained stable on CT scans, and she remained asymptomatic for 5 months after her first course of immunotherapy. However, tumor recurred 6 months after immunotherapy and she died 10 months after immunotherapy.

Figure 6 shows postcontrast CT scans in Case 6 with a glioblastoma multiforme in the right parietal lobe, manifesting as progressive left hemiparesis and seizures. Three weeks after LAK treatment $(10.9 \times$ $10^{7}$ cells), CT scans showed tumor disappearance and a decreased surrounding low-density area. Six months later, CT scans showed a mass lesion in the same area. The lesion was removed surgically, but there was no histological evidence of tumor cells in the specimens. He improved steadily with slight hemiparesis (total follow-up over 5 yrs).

Cases 4 and 5 with intracisternal dissemination of tumor cells received only two or three injections of LAK cells and IL-2. Their general conditions were very bad with disturbance of consciousness. Partial deterioration was observed and they died within 3 months of immunotherapy. The other four patients showed no change in the tumor with immunotherapy.
Wound problems consisting of scalp inflammation at the craniotomy site occurred in the first two patients receiving daily injection of IL-2 (Cases 1 and 2). Case 1 required surgery for revision of an infected wound. Another patient (Case 7) suffered decrease in general activity due to the treatment. CT scans demonstrated increases in cerebral edema around the treatment site. No other complications, such as neurological deficits, hydrocephalus, or seizure occurred (Table 1). No changes in hematological and biochemical profiles were observed.

IV. Local immune response by LAK cells and IL-2

To determine the mechanism of tumor regrowth, tumor tissues after immunotherapy were obtained from Cases 6 and 9 and prepared for immunohistological analysis. Figure 7 shows a thick proliferation of connective tissues surrounding the tumor cavity and a massive accumulation of lymphocytes. Immunohistochemical examination revealed that many lymphocytes were positive for Leu 4 and Leu 2a. In addition, although less prominent, a considerable number of anti-HLA-DR-positive cells were also found. 


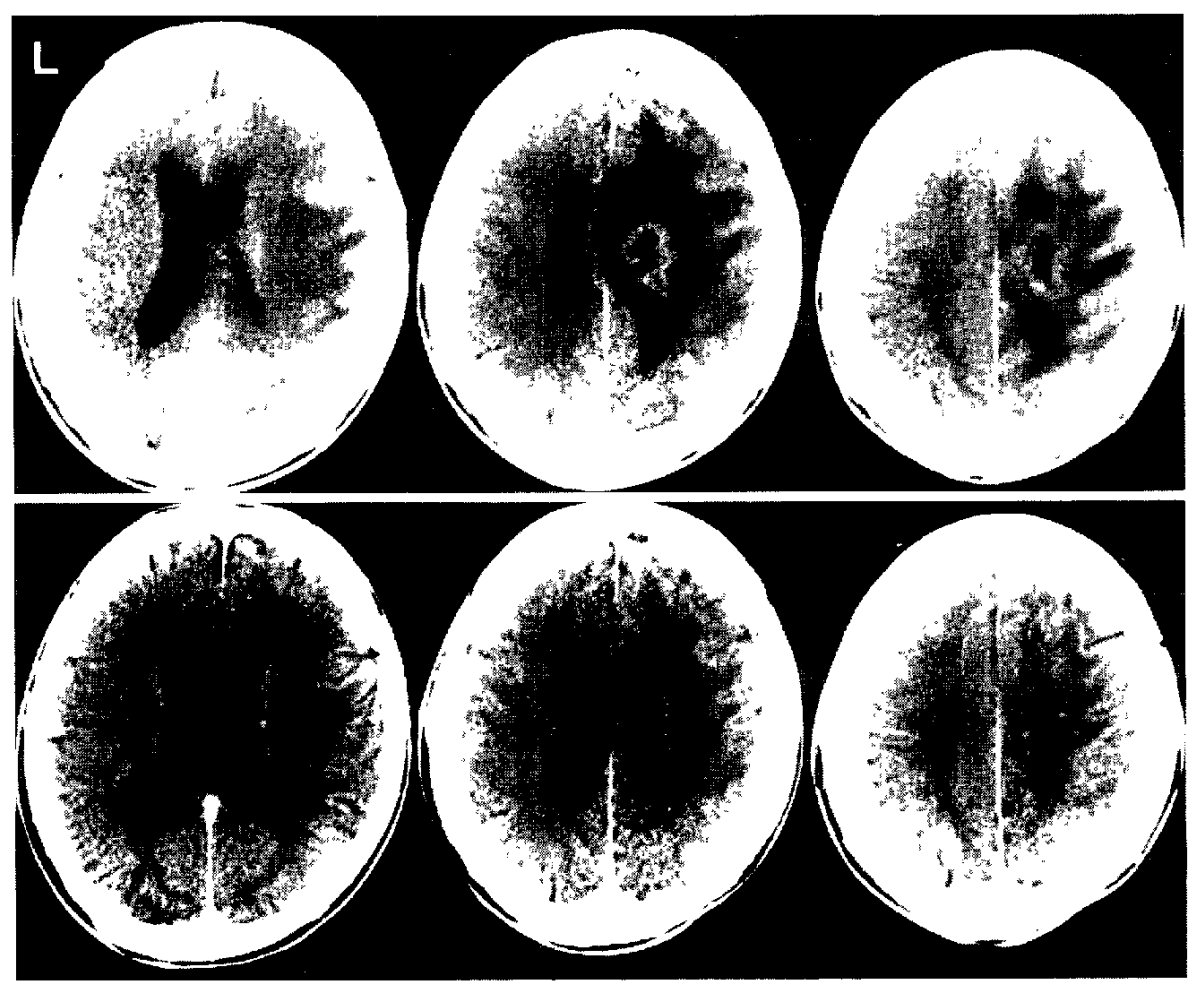

Fig. 6 Case 6. Postcontrast CT scans before (upper) and 3 weeks after immunotherapy (lower), showing disappearance of tumor.

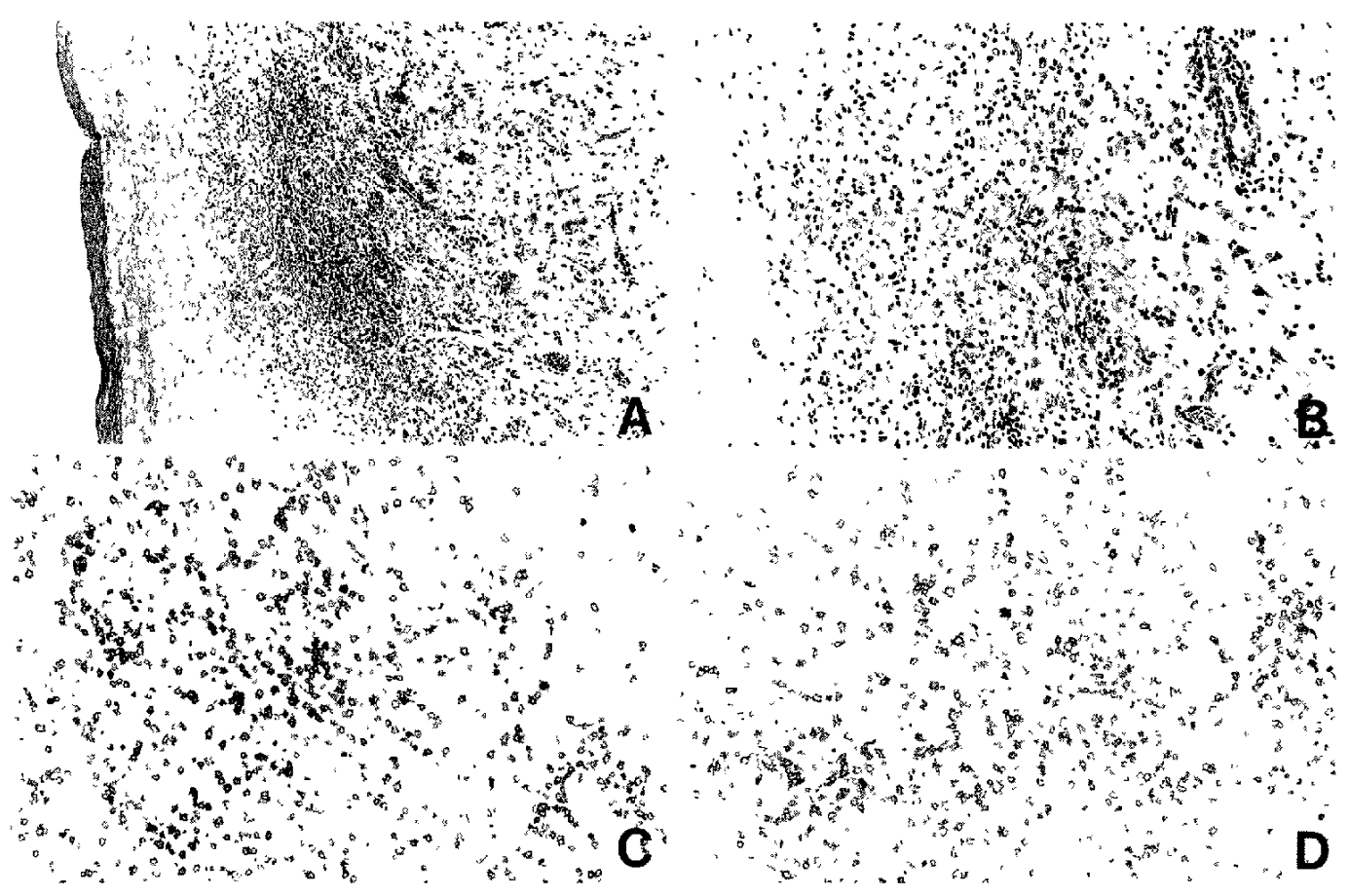

Fig. 7 Case 9. Immunohistological analysis of tumor tissues. A: HE stain, $\times 85$. B: Massive lymphocyte accumulation. $\times 170 . \mathrm{C}, \mathrm{D}$ : Mononuclear cells were stained by immunoperoxidase techniques with Leu 4 (C) and Leu $2 a$ MoAbs (D). $\quad \times 170$. 


\section{Discussion}

Immunotherapy is an attractive method of treatment for patients with malignant brain tumors, since it can potentially discriminate between malignant tumor and normal brain tissue. ${ }^{12)}$ Although the brain is considered to be an immunologically unique site, HLADR antigens, markers of antigen-presenting cells, occur in the brain parenchyma, ${ }^{20}$ ) suggesting that immunotherapy may be useful for the treatment of brain tumors. Takakura et al. ${ }^{22)}$ reported that transfusions of allogeneic bone marrow cells or intratumoral infusions of activated white blood cells resulted in increased survival times for patients with malignant brain tumors. Young et al.$^{30)}$ also treated 17 glioblastoma patients with injection of autologous leukocytes. Eight of the 17 patients improved clinically and survived for 17 months posttreatment. Other workers have shown benefit for patients with the same immunotherapy. ${ }^{3)}$

Grimm et al. ${ }^{4)}$ reported a new type of immunotherapy using LAK cells in the 1980s. Adoptive immunotherapy with LAK cells and/or IL-2 can be effective against established pulmonary metastases in animal models, ${ }^{15)}$ while immunotherapy with LAK cells and IL-2 has been successful in non-central nervous system cancer patients. ${ }^{17}$ Administration of only LAK cells to cancer patients causes minimal toxicity, but high doses of IL-2 result in significant toxic side effects, including fever, chills, malaise, anemia, thrombocytopenia, eosinophilia, and weight gain due to vascular leak syndrome. ${ }^{19)}$ Moreover, only few percent of LAK cells administered intravenously reach the tumor site. ${ }^{21)}$ Therefore, intratumoral injection of LAK cells with a small amount of IL-2 may be a more practical approach to deliver LAK cells to the tumor sites, especially in immunologically privileged sites like the brain. Jacobs et al. ${ }^{11)}$ demonstrated that patients with brain tumors tolerated intracranial infusion of a single dose of LAK cells and IL-2 without signs of toxicity. Other data suggest the effectiveness of intratumoral infusion of LAK cells and IL-2 in patients with brain tumors. ${ }^{2)}$

We previously demonstrated that the depletion of macrophages in PBLs resulted in a marked enhancement of LAK activity against both NK-sensitive and NK-resistant target cells. ${ }^{7}$ Using such LAK cells with strong cytotoxic activity (Fig. 2), we tried to determine the effectiveness of intratumoral infusion of LAK cells and a small amount of IL-2 in patients with malignant brain tumors. Figures 5 and 6 show that a reduction of tumor size or disappearance of the tumor was achieved within 3 weeks. The amounts of LAK cells injected intratumorally were only 5.9 and $10.9 \times 10^{7}$ cells, very few compared to standard LAK therapy. ${ }^{17)}$ The patients, except the first two, did not receive daily injection of IL-2 to avoid wound infection.

LAK cells may not survive without continued exposure to IL-2. ${ }^{157}$ However, we demonstrated that intratumoral infusion of $\mathrm{LAK}$ cells without IL-2 resulted in regression of rat syngeneic subcutaneous tumors. ${ }^{29)}$ Immunohistological analysis revealed prominent infiltration of cytotoxic/suppressor $\mathrm{T}$ cells in the LAK cell-treated tumor tissues, while few lymphocytes were present in control tumor tissues. We also found that systemic administration of high-dose IL-2 increased the number of intratumoral lymphocytes, the level of peritumoral lymphocytic transferrin, and the expression of HLA-DR and IL-2 receptors of tumor-infiltrating lymphocytes (TILs)." These results suggested that LAK cells and/or IL-2 may mediate tumor regression by inducing local host immunity against tumor cells. This hypothesis was supported by our present study showing a massive accumulation of cytotoxic/suppressor T lymphocytes in the LAK cell-treated tumor tissues (Fig. 7). Amplification of immune response is well known in the microenvironment of a tumor undergoing rejection. A cytokine cascade may be important in such immune amplification, involving various soluble factors. The intratumoral infusion of LAK cells may cause the lysis of tumor cells followed by cooperation of LAK cells and host-derived immune cells to trigger host regional immune responses with reactions magnified by the cytokine cascade, resulting in a massive accumulation of cytotoxic $T$ cells in the tumor tissues.

$1 \mathrm{~L}-2$ affects both the induction of LAK cells and the NK effector function. In vitro treatment of PBLs with IL-2 requires only a short time to augment NK cytotoxicity, ${ }^{24)}$ whereas in vivo treatment of cancer patients resulted in an increase in NK activity peaking 5 days after initiation. ${ }^{8)}$ Therefore, we analyzed the effect of intratumoral injection of LAK cells and IL-2 on NK cytotoxicity and lymphocyte subsets in PBLs. NK activity was almost parallel to the number of Leu 11 b-positive lymphocytes, while LAK activity was not associated with the changes in NK activity (Fig. 3). Other lymphocyte surface markers were not affected by intratumoral administration of LAK cells and IL-2 (Fig. 4). Whiteside et al ${ }^{28)}$ reported no relationship between NK cell activity of PBLs and generation of LAK cells during 48 hours of IL-2 activation. They also found no correlation between percentages of CD $16^{+}$or Leu $19^{+}$cells and NK cell activity in fresh PBLs from their patients with brain 
tumors. We previously demonstrated that metastatic lung cancer patients receiving $1000-10,000 \mathrm{U} / \mathrm{kg}$ of IL-2 systematically had low spontaneous TIL NK activity. ${ }^{1)}$ In contrast, spontaneous TIL NK activity was increased in patients receiving $15,000 \mathrm{U} / \mathrm{kg}$ of IL-2 preoperatively. Thus, high-dose administration of IL-2 affects TIL NK activity in vivo. These results may reflect differences in IL-2 dose and administration route.

Wound problems consisting of scalp inflammation at the craniotomy site occurred in our two patients who received daily injection of IL-2. Another patient suffered decreased general activity due to the treatment, and CT scans demonstrated increased cerebral edema around the treatment site. Both the neurological and radiological changes improved when treatment was stopped. No other complications, including neurological symptoms, hydrocephalus, vascular leak syndrome, or seizure, were observed. Barba et al. ${ }^{2)}$ reported neurological deficits due to IL-2 treatment, and CT scans showing increased cerebral edema around the tumor and treatment site. They also reported wound infections in four of nine patients. Scalp infection appeared to result from contact of the LAK cells and IL-2 in tumor cavity fluid with the scalp wound.

Anticonvulsants and steroids are widely used in patients with brain tumors. Phenytoin or steroid may be important in immunosuppression in such patients. Okamoto et al. ${ }^{(6)}$ reported that phenytoin suppressed the proliferative response of lymphocytes to mitogen, NK activity, and cytotoxic $\mathrm{T}$ lymphocyte activity, but not affected LAK activity. In our study, LAK activity was similar in phenytoin (or steroid) treated and non-treated patients (data not shown). The major side effect of IL-2 was fluid retention secondary to a generalized increase in capillary permeability, with resultant peripheral edema, ascites, and pleural effusion. Vetto et al. ${ }^{25)}$ reported that patients receiving corticosteroid showed markedly decreased immunoresponse while receiving IL-2. Therefore, these agents should be carefully used depending on the immunological condition of patients with malignant brain tumors. No changes in hematological and biochemical profiles were found, although Jacobs et al. ${ }^{11}$ reported that the white blood cell counts of few patients markedly increased post-treatment but without associated signs or symptoms. No malaise, skin reactions associated with allergic reactions, or other adverse effects were observed.

Tumors recurred in one responding patient (Case 8) 6 months later. LAK cells can kill tumor cells in vivo, but regional intratumoral injection of LAK cells still has limitations. Histological analysis revealed proliferation of thick connective tissues surrounding the tumor cavity after treatment with LAK cells (Fig. 7). The effects of LAK cells are limited because cell-to-cell contact is required to kill tumor cells. Moreover, glial tumor cells usually extend beyond the radiologically abnormal areas indicated by CT. Therefore, successful immunotherapy with LAK cells is dependent on delivering the LAK cells to distant residual tumor cells. Rosenberg et al. ${ }^{18)}$ demonstrated that TILs cultured with IL-2 can also mediate significant antitumor effects against established pulmonary and hepatic macrometastases when given systemically with IL-2. Such cells homing on distant tumor cells may be the solution to the problems of cell delivery. However, the problem is very few TILs in brain tumors.

Intratumoral infusion of LAK cells and IL-2 achieved partial response in three of nine patients with malignant brain tumors. This study demonstrated that immunotherapy of malignant brain tumors with LAK cells and IL-2 is theoretically possible but the limitations still require resolution.

\section{Acknowledgments}

The authors appreciate the provision of recombinant IL-2 by Takeda Chemical Industries, Ltd. and valuable comments on the manuscript by Dr. Hungyi Shau, Department of Surgical Oncology, University of California, Los Angeles, U.S.A.

This work was supported in part by Grants-in-Aid from the Ministry of Education, Science and Culture of Japan and the Akiyama Foundation, Japan.

\section{References}

1) Anderson $T M$, Ibayashi $Y$, Tokuda $Y$, Colquhoun $S$, Holmes C, Golub SH: Natural killer activity of lymphocytes infiltrating human lung cancers following preoperative systemic recombinant interleukin 2. Arch Surg 122: 1446-1450, 1987

2) Barba D, Saris SC, Holder C, Rosenberg SA, Oldfield EH: Intratumoral LAK cell and interleukin2 therapy of human gliomas. $J$ Neurosurg 70: $175-$ 182,1989

3) Bloom HJG, Peckham MJ, Richardson AE, Alexander PA, Payne PM: Glioblastoma multiforme: A controlled trial to assess the value of specific active immunotherapy in patients treated by radical surgery and radiotherapy. $\mathrm{Br} J$ Cancer 27: 253-267, 1973

4) Grimm EA, Mazumder A, Zhang HZ, Rosenberg SA: Lymphokine-activated killer cell phenomenon. Lysis of natural killer-resistant fresh solid tumor cells by interleukin 2 -activated autologous human peri- 
pheral blood lymphocytes. $J$ Exp Med 155: 1823 1841, 1982

5) Hinuma S, Onda H, Naruo K, Ichimori Y, Koyama $\mathrm{M}$, Tsukamoto $\mathrm{K}$ : Translation of interleukin 2 mRNA from human peripheral blood leukocytes in xenopus oocytes. Biochem Biophys Res Commun 109: 363-369, 1982

6) Ibayashi Y, Golub SH: Functional studies on lymphokine activated killer (LAK) cells against NK-sensitive and NK-resistant targets. Proc Am Assoc Cancer Res 27: 352, 1986

7) Ibayashi Y, Hoon DSB, Golub SH: The regulatory effect of adherent cells on lymphokine activated killer (LAK) cells. Cell Immunol 110: 365-378, 1987

8) Ibayashi Y, Tokuda Y, Saks ER, Sarna GP, Golub $\mathrm{SH}$ : In vivo and in vitro activation of NK cytotoxicity with IL-2, in Truitt R, Bortin MM, Gale RP (eds): Cellular Immunotherapy of Cancer. New York, Alan R Liss, 1987, pp 275-285

9) Ibayashi $Y$, Uede $T$, Uede $T$, Kikuchi K: Functional analysis of mononuclear cells infiltrating into tumors: Differential cytotoxicity of mononuclear cells from tumors of immune and nonimmune rats. $I$ Immunol 134: 648-653, 1985

10) Itoh $K$, Tilden AS, Kumagai $K$, Balch CM: Leu-11+ lymphocytes with natural killer (NK) activity are precursors of recombinant interleukin 2 (rIL 2)-induced activated killer (AK) cells. $J$ Immunol 134: 802-807, 1985

11) Jacobs SK, Wilson DJ, Kornblith PL, Grimm EA: Interleukin-2 and autologous lymphokine-activated killer cells in the treatment of malignant glioma. Preliminary report. I Neurosurg 64: 743-749, 1986

12) Jacobs SK, Wilson DJ, Melin G, Parham CW, Holcomb B, Kornblith PL, Grimm EA: Interleukin-2 and lymphokine activated killer (LAK) cells in the treatment of malignant glioma: Clinical and experimental studies. Neurol Res 8: 81-87, 1986

13) Lotze MT, Frana LW, Sharrow SO, Robb RJ, Rosenberg SA: In vivo administration of purified human interleukin 2. I. Half-life and immunologic effects of the Jurkat cell line-derived interleukin 2. $J$ Immunol 134: 157-166, 1985

14) Mahaley MS Jr, Urso MB, Whaley RA, Blue $M$, Williams TE, Guaspari A, Selker RG: Immunobiology of primary intracranial tumors. Part 10: Therapeutic efficacy of interferon in the treatment of recurrent gliomas. $J$ Neurosurg 63: 719-725, 1985

15) Mazumder A, Rosenberg SA: Successful immunotherapy of natural killer-resistant established pulmonary melanoma metastases by the intravenous adoptive transfer of syngeneic lymphocytes activated in vitro by interleukin 2. $J$ Exp Med 159: 495-507, 1984

16) Okamoto $Y$, Shimizu K, Tamura K, Miyao $Y$, Yamada M, Tsuda N, Matsui Y, Mogami H: Effects of phenytoin on cell-mediated immunity. Cancer Immunol Immunother 26: 176-179, 1988

17) Rosenberg SA, Lotze MT, Muul LM, Leitman S,
Chang AE, Ettinghausen SE, Matory YL, Skibber JM, Shiloni E, Vetto JT, Seipp CA, Simpson C, Reichert CM: Observations on the systemic administration of autologous lymphokine-activated killer cells and recombinant interleukin-2 to patients with metastatic cancer. $N$ Engl $J$ Med 313: 14851492,1985

18) Rosenberg SA, Packard BS, Aebersold PM, Solomon D, Topalian SL, Toy ST, Simon P, Lotze MT, Yang JC, Seipp CA, Simpson C, Carter C, Bock $S$, Schwartzentruber D, Wei JP, White DE: Use of tumor-infiltrating lymphocytes and interleukin-2 in the immunotherapy of patients with metastatic melanoma. A preliminary report. $N$ Engl J Med 319: $1676-1680,1988$

19) Rosenstein M, Ettinghausen SE, Rosenberg SA: Extravasation of intravascular fluid mediated by the systemic administration of recombinant interleukin 2. J Immunol 137: 1735-1742, 1986

20) Saito T, Tanaka R, Yoshida S, Washiyama K, Kumanishi $T$ : Immunohistochemical analysis of tumor-infiltrating lymphocytes and major histocompatibility antigens in human gliomas and metastatic brain tumors. Surg Neurol 29: 435-442, 1988

21) Sawamura Y, Hosokawa M, Kobayashi H, Itoh K: In vivo distribution of murine and human lymphokineactivated killer cells: Implication of adoptive immunotherapy. Biotherapy 2: 163-167, 1988

22) Takakura K, Miki Y, Kubo O, Ogawa N, Matsutani M, Sano K: Adjuvant immunotherapy for malignant brain tumors. Jpn J Clin Oncol 12: 109-120, 1972

23) Tanaka $R$, Sekiguchi $K$, Suzuki $Y$, Sobue $H$, Takaeda N, Murakami N: Local immunotherapy of malignant brain tumors: Evaluation of intratumoral injection of BCG and a Streptococcus pyogenes preparation. Neurol Med Chir (Tokyo) 24: 376-384, 1984 (in Japanese)

24) Trinchieri G, Matsumoto-Kobayashi M, Clark SC, Seehra J, London L, Perussia B: Response of resting human peripheral blood natural killer cells to interleukin 2. J Exp Med 160: 1147-1169, 1984

25) Vetto JT, Papa MZ, Lotze MT, Chang AE, Rosenberg SA: Reduction of toxicity of interleukin-2 and lymphokine-activated killer cells in humans by the administration of corticosteroids. $I$ Clin Oncol 5: 496-503, 1987

26) Walker MD, Alexander E Jr, Hunt HE, MacCarty CS, Mahaley MS Jr, Mealey J Jr, Norrell HA, Owens G, Ransohoff J, Wilson CB, Gehan EA, Strike TA: Evaluation of BCNU and/or radiotherapy in the treatment of anaplastic gliomas. A cooperative clinical trial. $J$ Neurosurg 49: 333-343, 1978

27) Walker MD, Green SB, Byar DP, Alexander E, Batzdorf U, Brooks WH, Hunt WE, MacCarty CS, Mahaley MS, Mealy J, Owens G, Ransohoff J, Shapiro WR, Smith KR, Wilson CB, Strike TA: Randomized comparisons of the radiotherapy and nitrosoureas for the treatment of malignant glioma after surgery. $N$ Engl J Med 303: 1323-1329, 1980 
28) Whiteside TL, Wang YL, Selker RG, Herberman RB: In vitro generation and antitumor activity of adherent lymphokine-activated killer cells from the blood of patients with brain tumors. Cancer Res 48: $6069-6075,1988$

29) Yamaki $T$, Ibayashi $Y$, Nakamura $T$, Shijubo $N$, Daibo M, Kawahara T, Hashi K: Immunotherapy of solid tumor by intratumoral infusion of lymphokineactivated killer cells. Jpn $J$ Cancer Res 79: 903-908, 1988

30) Young H, Kaplan A, Regelson W: Immunotherapy with autologous white cell infusions ("lymphocytes") in the treatment of recurrent glioblastoma multiforme. A preliminary report. Cancer 40: 10371044,1977

Address reprint requests to: Y. Ibayashi, M.D., Department of Neurosurgery, Sapporo Medical College, South-1, West-16, Chuo-ku, Sapporo 060, Japan. 